\title{
DNA extraction and amplification of the $r b c L$ (ribulose-1,5- bisphosphate carboxylase/oxygenase large subunit) gene of red seaweed Gracilaria sp. from Bahoi Waters, North Minahasa Regency
}

\section{Ekstraksi DNA dan Amplifikasi gen rbcL (ribulose-1,5-bisphosphate carboxylase/oxygenase large subunit) Alga Merah Gracilaria sp. dari Perairan Desa Bahoi Kabupaten Minahasa Utara}

\author{
Irvan R. Hengkengbala*1, Grevo S. Gerung ${ }^{2}$, and Stenly Wullur ${ }^{2}$ \\ ${ }^{1}$ Program Studi Magister Ilmu Perairan, Pascasarjana, Universitas Sam Ratulangi, \\ Jl. Kampus Unsrat Bahu, Manado 95115, Sulawesi Utara, Indonesia. \\ ${ }^{2}$ Fakultas Perikanan dan Ilmu Kelautan, Universitas Sam Ratulangi, Jl. Kampus Unsrat Bahu, \\ Manado 95115, Sulawesi Utara, Indonesia. \\ *E-mail: richardirvan444@gmail.com
}

\begin{abstract}
The quality of DNA extraction and gene amplification in algae are influenced by several factors including the characters and components of the algal cell wall. Therefore, extraction procedure that successfully works in one species of algae may fail for another type of algae. The present study was aimed to examine several DNA extraction techniques and $r b c L$ (ribulose-1,5-bisphosphate carboxylase/oxygenase large subunit) gene amplifications of Gracilaria sp. collected in Bahoi, North Minahasa (126 43 '48' N $125^{0} 1$ '33'E). DNA genom of Gracilaria sp. was extracted using conventional method (CTAB, Cetyltrimethyl ammonium Bromide), and commercial extraction kits (innuPrep Plant DNA Kit and Geneaid Genomic Plant Mini Kit). Amplification of $r b c L$ gene employed 2 primers (rbcL-aF; ATGTCACCACAAACAGAGACTA AAGC, rbcL-aR; GTAAAATCAAGT CCACCRCG, and rbcL-1F ATGTCACCACAAACAGAAAC, rbcL-724R TCGCATGTA-CC TGCAGTAGC under 2 different annealing temperatures $\left(45\right.$ and $\left.50^{\circ} \mathrm{C}\right)$. Genomic DNA of Gracilaria sp. was successfully extracted using Geneaid DNA Mini Kit (Plant) indicated by a DNA band on the agarose gel. $R b c L$ gene of Gracilaria sp. could be amplified using primer $1 \mathrm{~F}-724 \mathrm{R}$ and annealing temperature at $50^{\circ} \mathrm{C}$ indicated by a sharp DNA band at 300-400 bp (1kb marker, Solis Biodyne) as a partial amplification of the target gene.
\end{abstract}

Keywords: DNA; gene $r b c L$, red algae; Gracilaria sp.; minahasa regency.

Abstrak: Kualitas hasil ekstraksi DNA dan amplifikasi gen pada alga dipengaruhi oleh beberapa faktor diantaranya adalah karakter dan komponen penyususun dinding sel alga itu sendiri. Oleh karena itu, prosedur ekstraksi yang berhasil dilakukan pada pada satu jenis alga dapat saja gagal dilakukan untuk jenis alga lainnya. Penelitian ini dilakukan untuk mengkaji beberapa teknik ekstraksi DNA dan kondisi amplifikasi gen rbcL (ribulose-1,5bisphosphate carboxylase/oxygenase large subunit) pada alga jenis Gracilaria sp. dari perairan Bahoi, Minahasa Utara (126 43 '48' 'N 1251'33'E). Ekstraksi DNA Gracilaria sp. dilakukan menggunakan metode konvensional (CTAB, Cetyltrimethyl ammonium Bromide), dan menggunakan kit ekstraksi komersil (innuPrep Plant DNA Kit dan Geneaid Genomic Plant Mini Kit). Amplifikasi gen $r b c L$ dilakukkan menggunakan 2 pasang primer ( $r b c L$ aF; ATGTCACCACAAACAGAGACTA AAGC, $r b c L-a R$; GTAAAATCAAGTCCACCRCG, dan $r b c L-1 \mathrm{~F}$ ATGTCACCACA AACAGAAAC, $r b c L-724 \mathrm{R}$ TCGCATGTACCTGCAGTAGC dan 2 kondisi suhu annealing berbeda $\left(45\right.$ dan $50^{\circ} \mathrm{C}$ ). DNA genom alga (Gracilaria sp.) dapat diekstraksi menggunakan prosedur Geneaid DNA Mini Kit (Plant) yang ditandai adanya pita DNA pada gel agarose. Gen rbcL of Gracilaria sp. dapat diamplifikasi menggunakan pasangan primer $r b c L 1 \mathrm{~F}$ dan $724 \mathrm{R}$ pada suhu annealing $50^{\circ} \mathrm{C}$ yang ditandai dengan adanya pita DNA tebal pada posisi sekitar 300-400 bp (1 kb marker, Solis Biodyne). Munculnya pita DNA target pada posisi tersebut mengindikasikan keberhasilan amplifikasi gen target secara parsial.

Kata-kata kunci: DNA; gen $r b c L$; alga merah; Gracilaria sp.; kabupaten minahasa utara.

\section{PENDAHULUAN}

Alga merupakan salah satu sumber daya hayati perairan yang tumbuh melimpah di Indonesia
(Gerung, 2004). Jenis alga yang paling banyak terdapat di perairan Indonesia adalah Gracilaria, Eucheuma, Hypnea, Sargassum, Turbinaria, Gelidium (Sahri and Suparmi, 2009). Gracilaria 
merupakan jenis alga merah dari famili Gracilariaceae yang banyak ditemukan di perairan Indonesia (Sahri and Suparmi, 2009). Gracilaria terdiri dari 230 spesies (Lyra et al., 2015), yang habitatnya tersebar luas dari perairan pantai tropis, daerah temperatur sedang, sampai di daerah beriklim dingin. Jenis alga dari genus Gracilaria memiliki nilai ekonomis penting untuk memproduksi agar (Oyieke and Kokwaro, 1995; Vinobaba et al., 2016), menghasilkan etanol (Amanullah et al., 2013), sebagai pakan abalone (Iyer et al., 2004; Marinho-Sariano and Bourret, 2005), immunostimulan untuk udang (Maningas et al, 2013; Arizo et al., 2016), pengelolaan limbah (Sahu and Sahoo, 2013) serta untuk pengobatan penyakit (kanker, AIDS, peradangan, artritis, infeksi virus, bakteri dan jamur) (Almeida et al., 2011).

Analisis molekuler alga genus Gracilaria menggunakan sekuens gen $r b c \mathrm{~L}$ (ribulose-1,5bisphosphate carboxylase/oxygenase large subunit) telah dilakukan oleh beberapa peneliti, antara lain, yaitu Destombe dan Douglas (1991), Freshwater et al. (1994), Belorin et al. (2002), Gurgel et al. (2003), dan Lyra et al. (2015). Akan tetapi, ekstraksi DNA dan amplifikasi gen $r b c L$ dari jenis alga ini seringkali sulit didapat dalam jumlah dan kualitas yang ideal untuk analisis molekuler selanjutnya (Tuney and Sukatar, 2001). Ekstraksi DNA sebagai langkah paling awal yang dilakukan untuk analisis molekuler, seringkali mendapatkan hasil berbeda untuk masing-masing jenis alga, yang mana prosedur yang berhasil digunakan pada satu jenis alga dapat saja gagal digunakan untuk jenis alga lain (Doyle and Doyle, 1987). Beberapa faktor pembatas untuk mendapatkan DNA berkualitas dari alga adalah pada karakter dinding sel, komponen polisakarida kompleks, kandungan polifenol dan metabolit sekunder yang dihasilkan setiap jenis alga (Doyle and Doyle, 1990; Phillips et al., 2001; Tuney dan Sukatar, 2010).

Sejauh ini, prosedur ekstraksi DNA alga dilakukan dengan berbagai metode, baik konvensional (Hong et al.,1997; Wattier et al., 2000; Phillips et al., 2001) maupun menggunakan kit ekstraksi komersil (Geraldino et al., 2009; Ruenes, 2010; Kim et al., 2012; Tan Ji, 2013; Yang et al., 2013). Metode konvensional ekstraksi DNA alga (Doyle and Doyle, 1987) seringkali telah melalui beberapa bentuk modifikasi prosedur yang disesuaikan kondisi masing-masing jenis alga yang diteliti; sedangkan penggunaan kit ektraksi komersil dapat menghasilkan kualitas hasil ekstraksi berbeda untuk setiap pabrikan. Penelitian ini dilakukan untuk mengetahui efektifitas metode ekstraksi DNA menggunakan teknik konvensional dan kit ekstraksi komersil untuk mendapatkan total DNA serta menentukan kondisi PCR ideal untuk mengamplifikasi gen $r b c L$ pada alga merah Gracilaria sp.

\section{MATERIAL DAN METODA}

\section{Ekstraksi DNA genomik alga Gracilaria sp}

Sampel alga Gracilaria sp. berasal dari perairan Desa Bahoi, Kecamatan Likupang Barat, Kabupaten Minahasa Utara (pada titik koordinat $126^{\circ} 43^{\prime} 48^{\prime}$ ' LU-125 $5^{\circ}$ '33" BT). Sampel diambil dalam keadaan segar dan dimasukkan ke dalam tabung facon $50 \mathrm{ml}$, yang telah berisi etanol absolute; diberi label dan dibawa ke Laboratorium Biologi Molekuler dan Farmasitika Laut, Fakultas Perikanan dan Ilmu kelautan, Universitas Sam Ratulangi, untuk analisis molekuler selanjutnya.

Isolasi DNA alga dilakukan dengan menggunakan metode Cetyltrimethylammonium Bromide (CTAB) (Gurgui and Piel, 2010 dalam Uria, 2013) dan menggunakan metode ekstraksi DNA dari innuPrep Plant DNA Kit (Jerman) dan Geneaid Genomic Plant Mini Kit (Korea). Isolasi DNA genomik menggunakan $\mathrm{CTAB}$ diawali dengan merendam 1 gram thalus Gracilaria sp. dalam nitrogen cair digerus hingga menjadi bubuk; direndam dalam larutan lisis buffer $(50 \mathrm{mM}$ Tris- $\mathrm{Cl}$ pH 7,5, $50 \mathrm{mM}$ EDTA, $700 \mathrm{mM} \mathrm{NaCl}, 2 \%$ Sarkosil, 8 M Urea) sebanyak $500 \mu$ dan diinkubasi pada suhu $60^{\circ} \mathrm{C}$ selama 60 menit. Sampel selanjutnya diekstraksi (sebanyak 2 kali) dengan fenol/kloroform/isoamil-alkohol $(25: 24: 1)$ dan disentrifugasi pada kecepatan $11.000 \mathrm{rpm}$ selama 5 menit. Supernatan selanjutnya ditambahkan dengan kloroform sebanyak 1 kali volume larutan dan disentrifugasi pada $11.000 \mathrm{rpm}$ untuk menghilangkan sisa fenol.

Pengendapan polisakarida dilakukan dengan menambahkan $0.5 \%$ CTAB dan menginkubasi sampel pada suhu $60^{\circ} \mathrm{C}$ selama 10 menit; kemudian sentrifugasi pada $11.000 \mathrm{rpm}$ selama 5 menit. Pengendapan DNA dilakukan dengan menambahkan etanol absolut $95 \%$ sebanyak 2 kali volume supernatan, kemudian disentrifugasi pada kecepatan maksimum selama 3 menit. Pelet DNA, selanjutnya, dicuci dengan menggunakan etanol $70 \%$ dingin sebanyak dua kali untuk menghilangkan sisa garam dan CTAB. Pelet DNA dikeringanginkan dan dilarutkan dengan $50 \mu 1 \mathrm{ddH}_{2} 0$ atau EB buffer (EDTA $10 \mathrm{mM}$, Tris-Cl $50 \mathrm{mM}$, pH 7.0).

Isolasi DNA alga menggunakan innuPrep Plant DNA Kit dilakukan berdasarkan prosedur 
manual dari innuPrep Plant DNA Kit. Sampel alga Gracilaria sp. diambil dari bagian thalus sebanyak $25 \mathrm{mg}$, direndam dalam nitrogen $\left(\mathrm{N}_{2}\right)$ cair, digerus menggunakan mortar dan pestel steril.

Hasil homogenasi ditambahkan pada larutan lisis $400 \mu \mathrm{l}$ dan Proteinase K sebanyak $25 \mu 1$, divortex selama 5 detik dan diinkubasi selama 3 jam pada suhu $55^{\circ} \mathrm{C}$ menggunakan thermoblock. Sampel dipindahkan ke dalam prefilter yang ditempatkan dalam tabung receiver $2,0 \mathrm{ml}$ dan disentrifugasi pada kecepatan $12.000 \mathrm{rpm}$ selama 1 menit. Sebanyak $200 \mu 1$ larutan pengikat SBS ditambahkan ke dalam sampel yang dianalisis dan dihomogenkan menggunakan pipet. Sampel dimasukkan ke dalam spin filter dan ditempatkan dalam tabung receiver 2,0 $\mathrm{ml}$ yang baru kemudian disentrifugasi pada $12.000 \mathrm{rpm}$ selama 2 menit. Spin filter dipindahkan dalam tabung receiver $2,0 \mathrm{ml}$ yang baru, ditambahkan larutan pencuci HS sebanyak $500 \mu 1$ dan disentrifugasi pada kecepatan $12.000 \mathrm{rpm}$ selama 1 menit. Sampel dipindahkan pada tabung receiver $1,5 \mathrm{ml}$ yang baru, ditambahkan $750 \mu \mathrm{l}$ larutan pencuci MS, disentrifugasi pada kecepatan $12.000 \mathrm{rpm}$. Sampel dipindahkan pada tabung receiver $2,0 \mathrm{ml}$ yang baru, disentrifugasi pada kecepatan maksimum untuk menghilangkan sisa etanol. Spin filter ditempatkan dalam tabung elusi 2,0 ml, ditambahkan $150 \mu \mathrm{l}$ buffer elusi. Inkubasi dilakukkan pada suhu ruang selama 5 menit dan disentrifugasi pada kecepatan $10.000 \mathrm{rpm}$ selama 1 menit.

Isolasi DNA menggunakan Genomic DNA Mini Kit (Plant) Geneaid dilakukan mengikuti prosedur manual dari Genomic DNA Mini Kit (Plant) dari Geneaid yang dimodifikasi. Sampel alga Gracilaria sp. ditimbang seberat $50 \mathrm{mg}$, dimasukkan ke dalam tabung ependorf yang telah diisi $400 \mu 1$ buffer GPXI dan digerus dengan mikropestel. Sampel diinkubasi pada suhu $60^{\circ} \mathrm{C}$ selama 3 jam, diinversi setiap 15 menit. Elution buffer yang akan digunakan pada tahap elusi dipanaskan terlebih dahulu pada suhu $60^{\circ} \mathrm{C}$ selama 10 menit. Setelah diinkubasi ditambahkan100 $\mu 1$ buffer GP2, divortex dan diinkubasi dengan es selama 3 menit. Sampel dipindahkan ke dalam yang telah ditempatkan pada collection tube $2 \mathrm{ml}$, filter column kemudian dibuang setelah disentrifugasi pada $10.000 \mathrm{x}$ g selama 1 menit. Supernatan dipindahkan ke dalam 1,5 $\mathrm{ml}$ microcentifuge tube. GP3 buffer yang telah ditambah isopropanol dimasukkan sebanyak 1,5 volume supernatan kemudian di vortex selama 5 detik. Supernatan dipindahkan dalam $G D$ column yang telah ditempatkan pada $2 \mathrm{ml}$ collection tube dan disentrifugasi pada $14.000-16.000 \mathrm{x}$ g selama 2 menit. Hasil filtrasi dibuang. Buffer W1 ditambahkan sebanyak $400 \quad \mu 1$ kemudian disentrifugasi pada $14.000-16.000 \times \mathrm{g}$ selama 30 detik, hasil filtrasi dibuang. Washing buffer yang telah ditambah etanol dimasukkan sebanyak $600 \mu \mathrm{l}$, disentrifugasi pada $14.000-16.000 \mathrm{x} \mathrm{g}$ selama 1 menit, filtrat dibuang. GD column yang telah ditempatkan pada $2 \mathrm{ml}$ collection tube baru, disentrifugasi selama 3 menit pada $14.000-16.000 \mathrm{x}$ $\mathrm{g}$ untuk mengeringkan matriks kolom. Pencucian dengan washing buffer diulangi sekali lagi kemudian disentrifugasi pada $14.000-16.000 \mathrm{x} \mathrm{g}$ selama 30 detik, filtrat dibuang. GD column yang telah ditempatkan pada $2 \mathrm{ml}$ collection tube baru, disentrifugasi selama 3 menit pada 14.000-16.000 x $\mathrm{g}$ untuk mengeringkan matriks kolom. Pindahkan GD column pada $1,5 \mathrm{ml}$ microcentifuge tube yang baru. Tambahkan $100 \mu \mathrm{l}$ elution buffer yang telah dipanaskan atau TE buffer pada bagian tengah matriks kolom. Diamkan selama 3-5 menit untuk memastikan DNA larut dalam elution buffer atau $T E$ buffer dan disentrifugasi pada 14.000-16.000 x g selama 30 detik.

\section{Amplifikasi gen $r b c L$ alga Gracilaria sp}

Amplifikasi gen $r b c L$ dilakukan menggunakan mesin Polymerase Chain Reaction (PCR), Biometra. DNA genom yang berhasil diektraksi digunakan sebagai DNA template pada proses amplifikasi. Komponen yang digunakan dalam proses amplifikasi gen $r b c \mathrm{~L}$ adalah $2 x$ Ready to Load Mastermix 12,5 $\mu 1$, masing-masing primer 1 $\mu 1$, DNA template $1,5 \mu 1, \mathrm{ddH}_{2} \mathrm{O} 9 \mu \mathrm{l}$. Pasangan primer yang digunakan adalah; pasangan primer $r b c L$ aF (5'-ATG TCA CCA CAA ACA GAG ACT AAA GC-3') dan $r b c L$ aR (5'- GTA AAA TCA AGT CCA CCR CG-3') serta pasangan primer $r b c L-1 \mathrm{~F}$ (5'ATGTCACCACAAACAGAAAC3') dan $r b c L-724 \mathrm{R}$ (3'TCGCATGTACCTGCAG TAGC5') (Bafeel et al, 2012).

Amplifikasi gen $r b c L$ dilakukan pada kondisi suhu anneling berbeda, yaitu pada suhu $45^{\circ} \mathrm{C}$ dan $50^{\circ} \mathrm{C}$ menggunakan pengaturan suhu gradient. Kondisi PCR dimulai dengan predenaturasi pada suhu $95^{\circ} \mathrm{C}$ selama 3 menit, diikuti dengan 35 siklus proses yang terdiri atas; proses denaturasi pada sushu $95^{\circ} \mathrm{C}$ selama 30 detik, proses annealing sesuai perlakukan (pada suhu 45 dan $50^{\circ} \mathrm{C}$ ) selama 40 detik dan proses elongasi pada suhu $72^{\circ} \mathrm{C}$ selama 50 detik. Proses akhir amplifikasi dilakukan pada suhu $72{ }^{\circ} \mathrm{C}$ selama 2 menit. DNA hasil PCR divisualisasi menggunakan elektroforesis gel agarosa $1 \%, 80$ volt selama 40 menit dan diamati pada UV transiluminator. 


\section{HASIL DAN PEMBAHASAN}

\section{Amplifikasi gen $r b c \mathrm{~L}$ alga Gracilaria sp.}

Amplifikasi gen $r b c L$ dilakukan dengan menggunakan primer $r b c L$ aF-aR dan $r b c L \quad 1 \mathrm{~F}-724$ $\mathrm{R}$ dengan suhu annealing $50^{\circ} \mathrm{C}$ dan $45^{\circ} \mathrm{C}$ (Gambar $1)$.

Penggunaan primer gen $r b c L$ pada suhu annealing $50^{\circ} \mathrm{C}$ dan $45^{\circ} \mathrm{C}$ menunjukkan hasil amplifikasi yang berbeda. Amplifikasi gen $r b c L$ menggunakan primer $\mathrm{aF}-\mathrm{aR}$ pada suhu annealing $50^{\circ} \mathrm{C}$ dan $45^{\circ} \mathrm{C}$ tidak menunjukkan pita DNA pada lintasan sampel. Dari hasil ini dapat diduga bahwa penggunaan primer $r b c L$ aF-aR tidak komplementer dengan urutan basa pada DNA template. Pita DNA hanya muncul pada hasil amplifikasi menggunakan primer $r b c L 1 \mathrm{~F}-724 \mathrm{R}$ pada kondisi suhu annealing $50^{\circ} \mathrm{C}$ sedangkan pada suhu annealing $45^{\circ} \mathrm{C}$ tidak terlihat pita DNA. Hasil tersebut mengindikasikan bahwa pemilihan suhu annealing yang tepat dan primer yang komplementer urutan basa dengan DNA template pada proses amplifikasi dapat mempengaruhi hasil amplifikasi gen target. Hasil amplifikasi ini mendukung apa yang ditulis oleh Rychlik et al. (1990) menyatakan bahwa pemilihan suhu annealing yang tepat untuk primer merupakan salah satu parameter keberhasilan proses amplifikasi DNA dengan PCR. Rahayu and Nugroho (2015) menyatakan bahwa salah satu strategi untuk mendapatkan hasil amplifikasi yang ideal adalah dengan menentukkan suhu annealing yang tepat dengan cara menaikkan atau menurunkan suhu annealing secara bertahap $1^{0} \mathrm{C}$ sampai tercapai suhu yang sesuai.

Penggunaan primer $r b c L$ 1F-724R dan suhu annealing $50^{\circ} \mathrm{C}$, pita DNA target hasil amplifikasi muncul pada posisi panjang nukleotida sedikit diatas posisi pita marker $250 \mathrm{bp}$ (1kb marker, Solis Biodyne). Dapat diduga bahwa panjang nukleotida yang dapat teramplifikasi menggunakan primer rbcL 1F-724R dalam penelitian ini adalah sebesar 300 - 400 bp. Menurut Fay et al. (1997) hasil amplifikasi penuh gen target dengan menggunakan primer $r b c L$ 1F-724R dapat diamati dengan munculnya pita DNA pada panjang basa nukleotida sekitar 723 bp. Munculnya pita DNA target pada posisi antara $300-400$ bp dalam penelitian ini mengindikasikan keberhasilan amplifikasi gen target secara parsial.

\section{KESIMPULAN}

DNA genom alga Gracilaria sp. specimen RLB1 berhasil diekstraksi dengan metode kit komersial Geneaid Genomic DNA Mini Kit. Gen $r b c L$ alga Gracilaria sp. berhasil diamplifikasi dengan primer forward $1 \mathrm{~F}$ dan reverse $724 \mathrm{R}$ pada suhu annealing $50^{\circ} \mathrm{C}$ pada kisaran $300-400$ base pair. Posisi pita pada kisaran tersebut mengindikasikan keberhasilan amplifikasi gen target secara parsial.

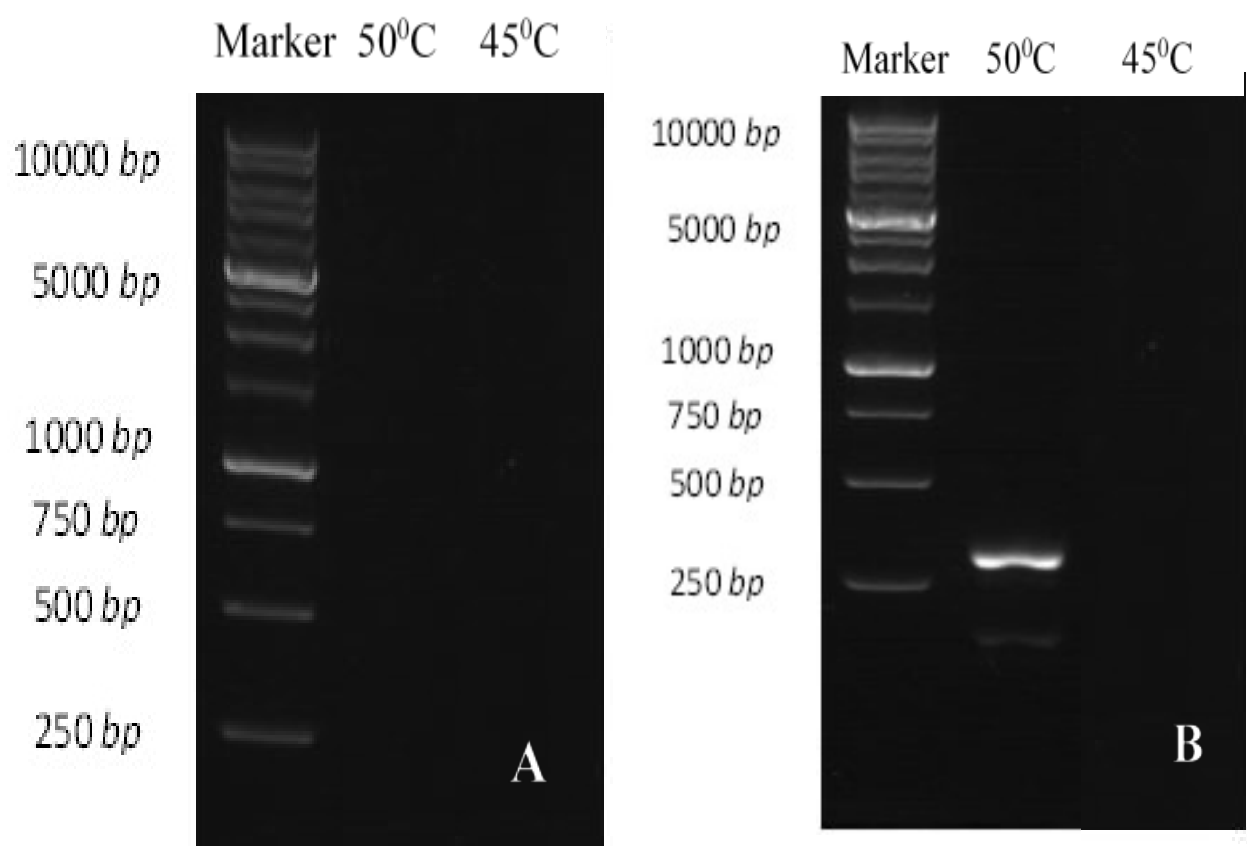

Gambar 1. Hasil amplifikasi gen $r b c L$ alga merah Gracilaria sp. pada suhu annealing $45^{\circ} \mathrm{C}$ dan $50^{\circ} \mathrm{C}$ dengan primer berbeda; A). primer $r b c L$ aF-aR, B). primer rbcL 1F-724R. 
Ucapan Terima Kasih: Terima kasih disampaikan kepada Beivy Kolondam S.Si, M.Si, MS sebagai kepala Laboratorium Bioteknologi Jurusan Biologi FMIPA-Unsrat yang telah membantu dalam tahapan ekstraksi DNA dan pengadaan primer untuk amplifikasi.

\section{REFERENSI}

ALMEIDA, C.L.F., FALCAO, H.D., LIMA, G.R. D., MONTENEGRO, C.D., LIRA, N.S. and DE ATHAYDE, P.F. (2011) Bioactivities from marine algae of the genus Gracilaria. International Journal of Molecular Sciences, 12(7), 4550-4573.

AMANULLAH, T.R., KRISHNAN, D., BALAJI, S.D. and GANESAN, K. (2013) Effective production of ethanol-from-cellulose (EFC) from cheap sources sawdust and seaweed Gracilaria edulis. Advances in Applied Science Research, 4(5), 213-222.

ARIZO, M.A.M., BERONCAL, R.A.G. and CHUA, W.A.K.T. (2016) Immune response of Macrobrachium rosenbergii immersed in aqueous extract of Gracilaria edulis challenged with white spot syndrome virus. AACL Bioflux, 9(2).

BELORIN, A.M., OLIVEIRA, M.C. and OLIVEIRA, E.C. (2002) Phylogeny and systematics of the marine algal family Gracilariaceae (Gracilariales, Rhodophyta) based on SSU rDNA and ITS sequences of Atlantic and Pacific species. Journal of Phycology, 38, 551-563.

DESTOMBE, C.I. and DOUGLAS, S.E. (1991) Rubisco Spacer Sequence Divergence in the Rhodophyte Alga Gracilaria Verrucosa and Closely Related Species. Curr. Genet. (5), 3958.

DOYLE, J.J. and DOYLE, J. (1990) Isolation of plant DNA from fresh tissue. Focus, 12:13.

DOYLE, J.J. and DOYLE, J.L. (1987) A rapid DNA isolation procedure for small quantities of fresh leaf tissue. Phytochem. Bull.

FAY, M.F., SWENSEN, S.M. and CHASE, M.W. (1997) Taxonomic affinities of Medusagyne oppositifolia (Medusagynaceae). Springer.

FRESHWATER, D.W., FREDERICQ, S., BUTLER, B.S, HOMMERSAND, M.H. and CHASE, M.W. (1994) A Gene Phylogeny Of The Red Algae (Rhodophyta) based on Plastid rbcL. Proc. Natl. Acad. Sci. USA 91, 72817285.
GERALDINO, J.P., CHANG, Y.E. and KIM, M.S. (2009) Systematics of Hypnea asiatica sp. nov. (Hypneaceae, Rhodophyta) Based on Morphology and nrDNA SSU, Plastid rbcL, and Mitochondrial Cox1. Taxon, 58(2), 606-616.

GERUNG, S.G. (2004) Biodiversity of Indonesian seaweeds. In: Marine Science into the New Millennium: New Perspective \& Challenges. Phang, S.M., Chong, V.C., Ho, S.C., Mokhtar, N. and Sim, J.O.L. pp. 41-54.

GURGEL, C.F.D., LIAO, L.M., FREDERICQ, S. and HOMMERSAND, M.H. (2003) Systematics of Gracilariopsis (Gracilariales, Rhodophyta) based on rbcL Sequence Analyses and Morphological Evidence. Journal of Phycology, 39, 154-171.

HONG, Y., KIM, S., POLNE-FULLER, M., GIBOR, A. (1997) DNA extraction conditions from Porphyra perforata using LiCI. Journal of Applied Phycology, 7, 101-107.

IYER, R., DE CLERCK, O., BOLTON, J.J. and COYNE, V.E. (2004) Morphological and taxonomic studies of Gracilaria and Gracilariopsis species (Gracilariales, Rhodophyta) from South Africa. South African Journal of Botany, 70(4), 521-539.

KIM, K.M., IL, K.H. and YOON, H.S. (2012) Four novel Gelidium species (Gelidiales, Rhodophyta) discovered in Korea: G. coreanum, G. jejuensis, G. minimum and G. prostratum. Phycologia, 51.

LYRA, G. M., COSTA, E.S., DE JESUS P.B., DE MATOS, J.C.G. and CAIRES, T.A. (2015) Phylogeny Of Gracilariaceae (Rhodophyta): Evidence from Plastid and Mitochondrial Nucleotide Sequences. Journal of Phycology, 51, 356-366.

MANINGAS, M.B.B., GONZALEZ, P.G. and OBIAS, M.M. (2013) Immune response of Macrobrachium rosenbergii immersed in hotwater extract of Gracilaria edulis. Philippine Science Letters, 6(2).

MARINHO-SORIANO, E. and BOURRET, E. (2005). Polysaccharides from the red seaweed Gracilaria dura (Gracilariales, Rhodophyta). Bioresource Technology, 96(3), 379-382.

OYIEKE, H.A. and KOKWARO, J.O. (1995) Distribution and ecology of Gracilaria species (Gracilariales, Rhodophyta) along the Kenyan Coast. South African Journal of Marine Science, 15(1), 43-48.

PHILLIPS, N., SMITH, C.M., MORDEN, C.W. (2001) An effective DNA extraction protocol for Brown Algae. Phycological Research, 49, 97-102. 
RAHAYU, D.A. and NUGROHO, E.D. (2015) Biologi Molekuler dalam Perspektif Konservasi. Plantaxia.

RUENES, J. (2010) DNA barcoding of Select Freshwater and Marine Red Algae (Rhodophyta). Cryptogamie, Algologie, 31 (4), 377-386.

RYCHLIK, W., SPENCER, W.J. and RHOADS, R.E. (1990) Optimization of the annealing temperature for DNA amplification in vitro. Nucleic Acids Research, 18(21).

SAHRI, A. and SUPARMI. (2009) Mengenal Potensi Alga : Kajian Pemanfaatan Sumber Daya Alga Dari Aspek Industri Dan Kesehatan. Sultan Agung, XLIV(118).

SAHU, N. and SAHOO, D. (2013) Study of Morphology and agar contents in some important Gracilaria species of Indian Coasts. American Journal of Plant Sciences, 4, 52-59.

TAN, J. (2013) Molecular Studies of Kappaphycus Doty and Eucheuma J. Agardh: Phylogenetics and DNA Barcode Assess-ment. Thesis. Kuala Lumpur: Institute of Biological Sciences Faculty of Science University of Malaya.
TUNEY, I. and SUKATAR, A. (2010) DNA extraction protocol from Brown Algae. Biological Diversity and Conservation.

URIA, A. (2013) Investigating Natural Product Biosynthesis in Uncultivated Symbiotic Bacteria of the Marine Sponge Theonella swinhoei. Disertation. Bonn: Universitat Bonn.

VINOBABA, P., KUMUDU and UMAKANTHAN, G. (2016) Distribution of Gracillaria species (Gracillaria edulis, Rhodophyta) in SriLanka. Researcher, 8(6), 50-58.

WATTIER, R.A., PRODOHL, P.A. and MAGGS, C.A (2000) DNA Isolation Protocol for Red Seaweed (Rhodophyta). Plant Molecular Biology Reporter, 18, 275-281.

YANG, E.C., KIM, M.S., GERALDINO, P.J.L., SAHOO, D., SHIN, J. and BOO, S.M. (2013) Mitochondrial cox 1 and Plastid rbcL Genes of Gracilaria vermiculophylla (Gracilaria-ceae, Rhodophyta). Journal of Applied Phycology, 20, 161-168.

Received: 3 May 2018 Accepted: 15 July 2018 